\title{
HUBUNGAN PERSEPSI IKLAN TERHADAP KEPUTUSAN PEMBELIAN PRODUK HERBISIDA (STUDI KASUS DI DESA ALUE SIJUEK KECAMATAN PEUDADA KABUPATEN BIREUEN)
}

\author{
The Correlation Between Perception Of Advertising And Decision Of Herbicide \\ Product Purchasing ( Study Case at Alue Sijuek Village, Peudada Districts, Regency \\ of Bireuen )
}

\author{
Rizka Alfinda Utami ${ }_{2}$, Romano ${ }^{1}$ Agustina Arida ${ }^{1 *}$ \\ ${ }^{1}$ Program Studi Agribisnis, Fakultas Pertanian, Universitas Syiah Kuala
}

\begin{abstract}
Abstrak. Pemanfaatan teknologi informasi yang meliputi media, metode, sistem dan kelembagaan serta dukungan permodalan sangat perlu untuk dikembangkan dan dioptimalkan perannya dalam mewujudkan pertanian nasional yang tangguh dan mampu bersaing dalam era pasar bebas yang akan datang. Kabupaten Bireun merupakan salah satu sentra produksi pertanian tanaman pangan yaitu padi. Sebagai salah satu daerah sumber penghasil beras di Provinsi Aceh maka banyak produsen sarana produksi pertanian mencoba mencari pasar yaitu dengan mengiklankan produk pertanian yang dihasilkan oleh usaha mereka. Penelitian ini dilakukan di Desa Alue Sijuek Kecamatan Peudada Kabupaten Bireuen. Pengambilan desa sampel dalam penelitian ini dilakukan dengan metode purposive sampling. jumlah populasi penelitian di Desa Alue Sijuek yaitu $101 \mathrm{KK}$, dengan demikian besarnya sampel dalam penelitian ini adalah 50\% dari total jumlah populasi yaitu sebanyak $51 \mathrm{KK}$ dengan metode analisis regresi linier berganda. Hasil penelitian ini adalah bahwa keputusan pembelian produk pertanian sangat dipengaruhi oleh persepsi petani yang terdiri dari sikap, motivasi, minat, pengalaman, harapan. Terdapat hubungan antara sikap, motivasi, dan harapan terhadap keputusan pembelian herbisida, sedangkan minat dan pengalaman tidak berhubungan dengan keputusan pembelian. Diharapkan kepada para petani dalam penggunaan produk pertanian dimana informasi yang diperoleh dari media cetak atau media elektronik, alangkah baiknya tetap dikonsultasikan dengan para pendamping atau penyuluh dilapangan, dikarenakan tidak semua produk yang diiklankan tersebut efektif terhadap tanaman pada daerah tertentu, hal ini dikarenakan pembuatan produk pertanian tersebut dibuat berdasarkan
\end{abstract}

Kata Kunci : Persepsi, Iklan, Keputusan Pembelian, Herbisida, Petani

\begin{abstract}
Utilization of information technology which includes media, method, system and institutional as well as capital support is very necessary to be developed and optimized its role in realizing a tough national agriculture and able to compete in the era of free market that will come. Bireun Regency is one of agricultural production centers of food crops, namely rice. As one of the rice producing regions in Aceh Province, many producers of agricultural production facilities try to find a market by advertising the agricultural products produced by their businesses. This research was conducted in Alue Sijuek Village, Peudada Sub-district, Bireuen District. Sampling sample in this research is done by purposive sampling method. total population of research in Alue Sijuek Village that is $101 \mathrm{KK}$, thus the amount of sample in this research is $50 \%$ from total of population amount that is $51 \mathrm{KK}$ with method of doubled linear regression analysis. The result of this research is that the decision of purchasing of agricultural product is very influenced by farmer perception consisting of attitude, motivation, interest, experience, expectation. There is a relationship between attitudes, motivations, and expectations of herbicide purchasing decisions, while interest and experience are not related to purchasing decisions. It is expected that farmers in the use of agricultural products where the information obtained from the print media or electronic media, it would be nice to be consulted with the counselor or field extension, because not all the products advertised are effective against the plant in certain areas, this is due to the manufacture of agricultural products are made based
\end{abstract}

Keywords : Perception, Advertising, Purchase Decision, Herbicides, Farmers 


\section{PENDAHULUAN}

Produk herbisida salah satu produk obat-obatan pertanian yang banyak dijumpai dengan berbagai jenis merk dan fungsinya. Sebagian besar produsen dalam memasarkan produk herbisida kepada para petani sebagai konsumen akhir mencoba memberikan informasi dengan media iklan baik media iklan elektronik maupun media iklan cetak. Hal ini diharapkan para petani dapat memberikan pertimbangan dalam memilih produk herbisida yang akan digunakan oleh para petani.

Kabupaten Bireun merupakan salah satu pusat produksi pertanian tanaman pangan yaitu padi. Sebagai salah satu daerah sumber penghasil beras di Provinsi Aceh maka banyak produsen sarana produksi pertanian mencoba menawarkan berbagai merk produk herbisida kepada para petani.

Herbisida merupakan bahan senyawa beracun yang dapat dimanfaatkan untuk membunuh tumbuhan pengganggu yang disebut gulma. Kehadiran gulma dalam lahan pertanian sangat tidak diharapkan karena akan menyaingi tanaman yang ditanam dalam memperolah unsur hara, air dan matahari. Akibat dari serangan gulma dapat menurunkan hasil panen yang cukup besar. Ditinjau dari cara kerjanya, herbisida dibedakan atas herbisida kontak akan mematikan jaringan gulma yang terkana. Herbisida ini diaplikasikan dengan penyemprotan dan sangat sesuai untuk mengendalikan gulma setahun atau gulma semusim. Serta Herbisida sistemik diabsorbsi oleh akar atau daun masuk ke dalam jaringan pembuluh kemudian diedarkan ke bagian lain sehingga gulma mengalami kematian total. Maka dari itu aplikasinya dapat dengan cara penyemprotan daun atau penyiraman ke akar tanaman.

Penggunaan herbisida saat ini sangat banyak variasinya dan disusaikan untuk mengatasi berbagai macam tanaman pengganggu pada usahatani. Oleh karena itu peran herbisida sebagai obat pelindung dari tanaman liar sangat penting dan kursial. Adapun produk herbisida yang banyak diperdagangkan di Kabupaten Bireuen terlihat pada Tabel 1 berikut :

Tabel 1. Jenis Produk Herbisida yang diperdagangkan di Kabupaten Bireuen, Tahun 2015.

\begin{tabular}{clrl}
\hline No & & Jenis Herbisida \\
\hline 1 & Ally & 14 & SUN-Up 480 AS, \\
2 & Round up & 15 & SDMA-6 \\
3 & Polaris & 16 & U46-D FLuit \\
4 & Spark & 17 & Wedar 720 AC \\
5 & Paracol & 18 & Basta 150 WSC \\
6 & Todomin 865 AS & 19 & Bimastar 240 AC \\
7 & Gramoxon & 20 & Tanton 240 AC \\
8 & Egle & 21 & Glyfomin \\
9 & Rhodiamine U 46 & 22 & Topan \\
10 & Tanistra & 23 & Ben Up \\
11 & Round Star & 24 & Serbu 160 AS \\
12 & Kimiru WP & 25 & Meta Prima 20 WDG \\
13 & Basmilang 480 AS & 26 & Ploris 240 AS \\
\hline
\end{tabular}

Sumber : Brigade Proteksi Kabupaten Bireuen, Tahun 2014

Berdasarkan Tabel 1 terlihat bahwa sebanyak 26 jenis produk herbisida yang umumnya dipergunakan oleh para petani di Kabupaten Bireuen yang dimana produk herbisida ini dapat dijumpai di 36 kios saprodi yang tersebar di Kabupaten Bireuen. 
Adapun produk herbisida tersebut mempunyai keunggulan dan kekurangan antara satu produk dengan produk lainnnya, baik dari efektivitasnya maupun dari harganya. Jumlah produsen herbisida yang banyak dijumpai pada produk herbisida di Kabupaten Bireuen seperti yang terlihat pada Tabel 2 berikut :

\section{Tabel 2. Produsen Produk Herbisida}

\begin{tabular}{cll}
\hline No & \multicolumn{1}{c}{ Nama Produsen } & \multicolumn{1}{c}{ Jenis Produk Herbisida } \\
\hline 1 & Sigenta & Gramoxone, Touchdown \\
\hline 2 & Petrokimia & Amexone 500 F, Amexon 80 WP, \\
& & Basmilang 480 AS, Bigstar 240/120 AS, \\
& & Komodor 300/100 AS, Kimiru 45 WP, \\
& & Lindas 240 AS, Maron 500 F, Maron 80 \\
& & WP, Pantom 200 AS, Saturn-D 6 G, \\
& & Starmin 865 AS \\
\hline 3 & Bayer & Rumpas 120 EW \\
\hline 4 & Nordox & Ally 20 WG, Basta 150 SL, Garlon 670 \\
& & EC, Gramoxone 276 SL, Hyvar 80 WP, \\
& & Karmex 80 WP, Kenlon 480 EC, \\
& & Lindomin 865 SL, Noxone 297 SL, \\
& & Rambo 480 SL, Round Up 486 SL, \\
& & Speed Up 480 SL, Starane 290 EC, \\
& & Tuntas 300/100 SL \\
\hline
\end{tabular}

Sumber : Dinas Pertanian Kabupaten Bireuen, Tahun 2014.

Dari banyaknya produk herbisida yang ditawarkan oleh produsen kepada para petani di Kabupaten Bireuen tentunya mempunyai beragam kelebihan dan kekurangan sehingga para petani dalam memilih produk juga melihat kelebihan dan kekurangan produk tersebut, sehingga pada akhirnya petani harus mengambil keputusan pembelian terhadap merk herbisida yang harus digunakan. Keputusan pembelian tersebut tentunya sangat berhubungan dengan persepsi petani itu sendiri terhadap produk herbisida. Persepsi petani timbul karena faktor sikap, motivasi, minat, pengalaman dan harapan.

Persepsi akan menentukan niat beli konsumen terhadap produk. Sikap merupakan aspek dari persepsi, dengan demikian petani memiliki sikap tersendiri untuk menentukan merek mana yang akan dipilihnya. Dalam upaya menentukan merek mana yang akan dipilihnya, maka petani dihadapkan dengan dua pilihan yang harus dipilihnya, sehingga terciptalah suatu keputusan membeli. Sedangkan faktor motivasi mempunyai hubungan pada tingkah laku petani dalam membuat keputusan pembelian. Dimana tingkah laku konsumen berhubungan dengan motivasinya akan mengurangi ketidakcocokan dalam membeli sesuatu, pada saat konsumen amat sangat terlibat dalam pembelian barang yang mahal, sehingga jarang membeli barang tersebut, namun mereka masih melihat sedikit perbedaan diantara merk-merk yang lainnya.

Menurut Arida (2016) mengatakan bahwa factor-faktor yang mempengaruhi motivasi adalah umur,pendapatan, pendidikan dan pengalaman. Umur, pendapatan dan pendidikan berpengaruh nyata trhadap motivasi petani yang dibuktikan dengan nilai signifikan lebih kecil dari $\alpha$. Sedangkan pengalaman petani tidak berpengaruh nyata terhadap motivasi dibuktikan dengan nilai signifikan lebih besar dari nilai $\alpha$. Nilai $\alpha$ yang digunakan adalah 0.05 atau $95 \%$. 
Untuk faktor minat beli para petani, minat beli sebagai kemungkinan seorang konsumen untuk berminat membeli suatu produk, sehingga terciptanya keputusan pembelian, selain itu keputusan pembelian hal ini juga dipengaruhi factor pengalaman dimana petani yang telah mempunyai pengalaman lebih banyak maka mengetahuui produk dan jenis produk apa yang harus digunakan dalam mengatasi gulma pada usahatani dan yang terakhir adalah factor harapan dimana produk herbisida yang tidak memenuhi harapan, petani merasa tidak puas, dan sebaliknya bila memenuhi harapan, petani merasa puas sehingga memberikan kepastian terhadap keputusan pembelian. Berdasarkan kondisi di atas, maka peneliti tertarik untuk melihat tentang hubungan persepsi petani pada iklan sarana produk pertanian terhadap keputusan pembelian produk herbisida di Desa Alue Sijuek Kecamatan Peudada Kabupaten Bireuen.

Tujuan lainnya adalah untuk mengetahui hubungan persepsi petani pada iklan sarana produk pertanian terhadap keputusan pembelian herbisida di Desa Alue Sijuek Kecamatan Peudada Kabupaten Bireuen

\section{METODE PENELITIAN}

Metode yang digunakan dalam penelitian ini adalah studi kasus. Hal ini disebabkan kawasan Desa Alue Sijuek Kecamatan peudada merupakan areal pertanian tanaman pangan dan merupakan Kecamatan yang mempunyai areal pertanian paling luas dibandingkan kecamatan lainnya di Kabupaten Bireuen mencapai 2.164. Populasi dalam penelitian ini adalah petani yang berada di desa Alue Sijuek Kecamatan Peudada Kabupaten Bireuen. Pengambilan desa sampel dalam penelitian ini dilakukan dengan metode purposive sampling. Hal ini disebabkan desa Alue sijuek mempunyai areal pertanian padi sawah paling luas di Kecamatan Peudada mencapai 120 Ha selain itu di daerah itu banyak dijumpai kelompok tani sehingga memudahkan penyampaian segala informasi pertanian kepada petani melalui kelompok taninya masing-masing salah satunya iklan produk sarana pertanian. Penelitian ini dilakukan pada petani yang membeli produk herbisida berdasarkan iklan yang didengar, dibaca dan dilihat. Adapun jumlah populasi penelitian di Desa Alue Sijuek yaitu $101 \mathrm{KK}$, dengan demikian besarnya sampel dalam penelitian ini adalah $50 \%$ dari total jumlah populasi yaitu sebanyak $51 \mathrm{KK}$.

Untuk menjawab hipotesis analisis yang digunakan untuk mengetahui hubungan antara keputusan pembelian dengan faktor-faktor persepsi maka digunakan model analisis tabulasi silang (crosstab).

\section{HASIL DAN PEMBAHASAN}

\section{Karakteristik Responden}

Karakterisrik petani adalah suatu keadaan petani pada usahatani padi sawah di daerah penelitian. Karakteristik yang dimaksud dalam penelitian ini meliputi umur, pendidikan, pengalaman berusahatani, jumlah tanggungan keluarga, luas lahan dan modal. Karakteristik tersebut akan mempengaruhi terhadap kegiatan, ketrampilan dan kemampuan petani untuk mengkombinasikan penggunaan faktor-faktor produksi serta pengambilan keputusan dalam berusahatani yang kesemuanya ini bertujuan untuk meningkatkan produksi dan pendapatan petani.

Hasil penelitian memperlihatkan keadaan karakteristik petani sampel di daerah penelitian seperti terlihat pada Tabel 3 berikut. 
Tabel 3. Rata-rata Karakteristik Petani Pada Usahatani Padi Sawah di Daerah Penelitian Musim Tanam 2017.

\begin{tabular}{|c|l|l|c|}
\hline No & \multicolumn{1}{|c|}{ Karakteristik } & Satuan & Rata-rata \\
\hline 1. & Luas Lahan & Ha & 1,20 \\
2. & Jenis Kelamin & Orang & \\
& $-\quad$ Laki-laki & Orang & 42 \\
& $-\quad$ Perempuan & Tahun & 9 \\
3. & Umur Petani & Tahun & 49,69 \\
4. & Tingkat Pendidikan & Tahun & 10 \\
5. & Lama Bekerja & Jiwa & 23 \\
6 & Jumlah Tanggungan & & 4 \\
\hline
\end{tabular}

Sumber: Data Primer Diolah,Tahun 2017.

Tabel 3 di atas menunjukkan bahwa luas lahan rata-rata yang dimiliki oleh para petani seluas 1,20 Ha. Serta jumlah petani perempuan hanya 9 orang sisanya adalah petani laki-laki sebanyak 42 orang. Sedangkan umur rata-rata petani padi sawah di daerah penelitian adalah 49,69 tahun. Umur ini digolongkan kedalam usia produktif. Pengertian produktif disini adalah adanya kemampuan untuk berproduksi atau menghasilkan, pada penelitian ini khususnya untuk melaksanakan usahatani padi sawah. Umur sangat menentukan kemampuan seseorang dalam bekerja. Dalam umur produktif seseorang mempunyai peluang besar untuk meningkatkan produktivitasnya.

Tingkat pendidikan petani di daerah penelitian 10 tahun. Hal ini berarti tingkat pendidikan petani telah mencapai Sekolah Menengah Tingkat Pertama. Sedangkan rata-rata pengalaman bertani padi sawah adalah 23 tahun dengan jumlah tanggungan rata-rata petani sampel adalah 4 jiwa.

Analisis Hubungan Persepsi Petani Pada Iklan Produk Sarana Pertanian Terhadap Keputusan Pembelian Produk Herbisida Oleh Petani Di Desa Alue Sijuek Kecamatan Peudada Kabupaten Bireuen

Adapun hubungan antara keputusan pembelian dengan sikap dapat dilihat pada Tabel 4.

Tabel 4. Analisis Chi Square Hubungan Antara Keputusan Pembelian dengan Sikap Konsumen di Daerah Penelitian, Tahun 2017

\begin{tabular}{ccccccccc}
\hline \multirow{2}{*}{ No } & $\begin{array}{r}\text { Keputusan } \\
\text { Pembelian }\end{array}$ & $\begin{array}{c}\text { Tidak } \\
\text { Setuju }\end{array}$ & $\begin{array}{c}\text { Kurang } \\
\text { Setuju }\end{array}$ & Setuju & Total & $\begin{array}{c}\text { Chi } \\
\text { Square }\end{array}$ & $\begin{array}{c}\text { Asymp. } \\
\text { Sig }\end{array}$ \\
\cline { 3 - 6 } & & 0 & 3 & 0 & 3 & & \\
$139.5-154.5$ & $\mathrm{ml}$ & & & & & 14,177 & 0,028 \\
\hline 2 & $155-170 \mathrm{ml}$ & 1 & 8 & 0 & 9 & & \\
\hline
\end{tabular}




\begin{tabular}{|c|c|c|c|c|c|c|c|}
\hline \multirow[b]{2}{*}{ No } & \multirow{2}{*}{$\begin{array}{l}\text { Keputusan } \\
\text { Pembelian }\end{array}$} & \multicolumn{3}{|c|}{ Sikap } & \multirow[b]{2}{*}{ Total } & \multirow{2}{*}{$\begin{array}{c}\text { Chi } \\
\text { Square }\end{array}$} & \multirow{2}{*}{$\begin{array}{c}\text { Asymp. } \\
\text { Sig }\end{array}$} \\
\hline & & $\begin{array}{l}\text { Tidak } \\
\text { Setuju }\end{array}$ & $\begin{array}{c}\text { Kurang } \\
\text { Setuju }\end{array}$ & Setuju & & & \\
\hline \multirow{4}{*}{3} & $170.5-185.5$ & 1 & 20 & 0 & 21 & & \\
\hline & $\mathrm{ml}$ & & & & & & \\
\hline & $185-200 \mathrm{ml}$ & 6 & 9 & 3 & 18 & & \\
\hline & Total & 8 & 40 & 3 & 51 & & \\
\hline
\end{tabular}

Berdasarkan Tabel 4 di atas dapat dilihat jumlah responden berdasarkan keputusan pembelian dengan sikap konsumen, dimana keputusan pembelian terbanyak yaitu pada pembelian 170,5 - 185,5 ml dengan jumlah responden 21 orang, dimana dari 21 orang sebanyak 20 orang menyatakan sikap kurang setuju. Sedangkan keputusan pembelian terkecil yaitu 139,5 - 154,5 ml dengan jumlah responden sebanyak 3 orang dan menyatakan kurang setuju bahwa sikap berhubungan dengan keputusan pembelian produk herbisida.

Sedangkan berdasarkan hasil analisis chi square dimana nilai chi square sebesar 14,177 dengan signifikan < 0,05 yaitu 0,028, maka Ho ditolak, artinya terdapat hubungan antara keputusan pembelian dengan sikap petani. Artinya keputusan pembelian oleh petani pada produk herbisida dipengaruhi oleh sikap petani dalam terhadap produk herbisida yang ada di iklan, sehingga para petani berkeyakinan bahwa produk tersebut dapat dibeli dan dipergunakan untuk keperluan kegiatan pertanian.

\section{Hubungan Keputusan Pembelian Dengan Motivasi}

Adapun hubungan antara keputusan pembelian dengan Motivasi dapat dilihat pada Tabel dibawah ini :

Tabel 5. Analisis Chi Square Hubungan Antara Keputusan Pembelian dengan Sikap Konsumen di Daerah Penelitian, Tahun 2017

\begin{tabular}{|c|c|c|c|c|c|c|c|}
\hline \multirow[b]{2}{*}{ No } & \multirow[b]{2}{*}{$\begin{array}{l}\text { Tingkat } \\
\text { Partisipasi }\end{array}$} & \multicolumn{3}{|c|}{ Motivasi } & \multirow[b]{2}{*}{ Total } & \multirow[b]{2}{*}{$\begin{array}{c}\text { Chi } \\
\text { Square }\end{array}$} & \multirow[b]{2}{*}{$\begin{array}{c}\text { Asymp. } \\
\text { Sig }\end{array}$} \\
\hline & & $\begin{array}{c}\text { Tidak } \\
\text { Setuju }\end{array}$ & $\begin{array}{c}\text { Kurang } \\
\text { Setuju }\end{array}$ & Setuju & & & \\
\hline 1 & $\begin{array}{l}139.5-154.5 \\
\mathrm{ml}\end{array}$ & 0 & 1 & 2 & 3 & \multirow{5}{*}{14,701} & \multirow{5}{*}{0,023} \\
\hline 2 & $155-170 \mathrm{ml}$ & 1 & 4 & 4 & 9 & & \\
\hline 3 & $\begin{array}{l}170.5-185.5 \\
\mathrm{ml}\end{array}$ & 0 & 6 & 15 & 21 & & \\
\hline 4 & $185-200 \mathrm{ml}$ & 0 & 14 & 4 & 18 & & \\
\hline & Total & 1 & 25 & 25 & 51 & & \\
\hline
\end{tabular}

Berdasarkan Tabel 5 di atas dapat dilihat jumlah responden berdasarkan keputusan pembelian dengan motivasi konsumen, dimana keputusan pembelian terbanyak yaitu pada pembelian 170,5 - 185,5 ml dengan jumlah responden 21 orang, dimana dari 21 orang sebanyak 15 orang menyatakan sikap setuju. Sedangkan keputusan pembelian terkecil yaitu 139,5 - 154,5 ml dengan jumlah responden sebanyak 3 orang dan menyatakan 2 orang konsumen menyatakan setuju serta sisanya 
sebanyak 1 orang kurang setuju. Hal ini menggambarkan bahwa motivasi berhubungan dengan keputusan pembelian produk herbisida.

Berdasarkan hasil analisis chi square dimana nilai chi square sebesar 14,701 dengan signifikan $<0,05$ yaitu 0,023 , maka Ho ditolak, artinya terdapat hubungan antara keputusan pembelian dengan motivasi petani. Artinya keputusan pembelian oleh petani pada produk herbisida dipengaruhi oleh motivasi petani dalam terhadap produk herbisida yang ada di iklan, dimana dengan adanya motivasi bahwa produk tersebut bekerja sesuai dengan apa yang disampaikan dalam iklan produk herbisida, sehingga petani membuat keputusan membeli produk herbisida tersebut.

\section{Hubungan Keputusan Pembelian Dengan Minat}

Adapun hubungan antara partisipasi dengan kepercayaan petani dapat dilihat pada Tabel dibawah ini :

Tabel 6. Analisis Chi Square Hubungan Antara Keputusan Pembelian dengan Minat Petani di Daerah Penelitian, Tahun 2017

\begin{tabular}{|c|c|c|c|c|c|c|c|}
\hline \multirow[b]{2}{*}{ No } & \multirow[b]{2}{*}{$\begin{array}{l}\text { Tingkat } \\
\text { Partisipasi }\end{array}$} & \multicolumn{3}{|c|}{ Minat } & \multirow[b]{2}{*}{ Total } & \multirow[b]{2}{*}{$\begin{array}{c}\text { Chi } \\
\text { Square }\end{array}$} & \multirow[b]{2}{*}{$\begin{array}{c}\text { Asymp. } \\
\text { Sig }\end{array}$} \\
\hline & & $\begin{array}{c}\text { Kurang } \\
\text { Setuju }\end{array}$ & Setuju & $\begin{array}{l}\text { Sangat } \\
\text { Setuju }\end{array}$ & & & \\
\hline 1 & $\begin{array}{l}139.5-154.5 \\
\mathrm{ml}\end{array}$ & 0 & 3 & 0 & 3 & \multirow{5}{*}{4,466} & \multirow{5}{*}{0,614} \\
\hline 2 & $155-170 \mathrm{ml}$ & 0 & 6 & 3 & 9 & & \\
\hline 3 & $\begin{array}{l}170.5-185.5 \\
\mathrm{ml}\end{array}$ & 1 & 17 & 3 & 21 & & \\
\hline 4 & $185-200 \mathrm{ml}$ & 2 & 14 & 2 & 18 & & \\
\hline & Total & 3 & 40 & 8 & 51 & & \\
\hline
\end{tabular}

Berdasarkan Tabel 6 di atas dapat dilihat jumlah responden berdasarkan keputusan pembelian dengan minat konsumen, dimana keputusan pembelian terbanyak yaitu pada pembelian 170,5 - 185,5 ml dengan jumlah responden 21 orang, dimana dari 21 orang sebanyak 17 orang menyatakan sikap setuju. Sedangkan keputusan pembelian terkecil yaitu 139,5 - 154,5 $\mathrm{ml}$ dengan jumlah responden sebanyak 3 orang dan menyatakan 3 orang konsumen menyatakan setuju. Hal ini menggambarkan bahwa minat berhubungan dengan keputusan pembelian produk herbisida.

Sedangkan Berdasarkan hasil analisis chi square dimana nilai chi square sebesar 4,466 dengan signifikan > 0,05 yaitu 0,614, maka Ho ditolak, artinya tidak terdapat hubungan antara keputusan pembelian dengan minat petani. Artinya keputusan pembelian oleh petani pada produk herbisida tidak dipengaruhi oleh minat petani dalam terhadap produk herbisida karena tidak ada produk sesuai harapan petani secara keseluruhan sehingga minat tidak berhubungan dengan keputusan pembelian.

\section{Hubungan Keputusan Pembelian Dengan Pengalaman}

Adapun hubungan antara keputusan pembelian dengan pengalaman dapat dilihat pada Tabel dibawah ini : 
Tabel 7. Analisis Chi Square Hubungan Antara Keputusan Pembelian dengan Pengalaman Petani di Daerah Penelitian, Tahun 2017

\begin{tabular}{|c|c|c|c|c|c|c|c|}
\hline \multirow[b]{2}{*}{ No } & \multirow[b]{2}{*}{$\begin{array}{c}\text { Tingkat } \\
\text { Partisipasi }\end{array}$} & \multicolumn{3}{|c|}{ Pengalaman } & \multirow[b]{2}{*}{ Total } & \multirow{2}{*}{$\begin{array}{c}\text { Chi } \\
\text { Square }\end{array}$} & \multirow[b]{2}{*}{$\begin{array}{c}\text { Asymp. } \\
\text { Sig }\end{array}$} \\
\hline & & $\begin{array}{c}\text { Kurang } \\
\text { Setuju }\end{array}$ & Setuju & $\begin{array}{l}\text { Sangat } \\
\text { Setuju }\end{array}$ & & & \\
\hline 1 & $\begin{array}{l}139.5-154.5 \\
\mathrm{ml}\end{array}$ & 0 & 2 & 1 & 3 & & \\
\hline 2 & $155-170 \mathrm{ml}$ & 0 & 7 & 2 & 9 & & \\
\hline 3 & $\begin{array}{l}170.5-185.5 \\
\mathrm{ml}\end{array}$ & 2 & 18 & 1 & 21 & 4,202 & 0,649 \\
\hline 4 & $185-200 \mathrm{ml}$ & 2 & 13 & 3 & 18 & & \\
\hline & Total & 1 & 21 & 12 & 34 & & \\
\hline
\end{tabular}

Berdasarkan Tabel 7 di atas dapat dilihat jumlah responden berdasarkan keputusan pembelian dengan pengalaman konsumen, dimana keputusan pembelian terbanyak yaitu pada pembelian 170,5 - 185,5 ml dengan jumlah responden 21 orang, dimana dari 21 orang sebanyak 18 orang menyatakan sikap setuju. Sedangkan keputusan pembelian terkecil yaitu 139,5 - 154,5 $\mathrm{ml}$ dengan jumlah responden sebanyak 3 orang dan menyatakan 2 orang konsumen menyatakan setuju sisanya menyatakan sangat setuju. Hal ini menggambarkan bahwa minat berhubungan dengan keputusan pembelian produk herbisida.

Sedangkan Berdasarkan hasil analisis chi square dimana nilai chi square sebesar 4,202 dengan signifikan > 0,05 yaitu 0,649, maka Ho ditolak, artinya tidak terdapat hubungan antara keputusan pembelian dengan pengalaman petani. Artinya keputusan pembelian oleh petani pada produk herbisida tidak dipengaruhi oleh pengalaman petani dalam terhadap produk herbisida yang ada di iklan, dimana sebuah produk tentunya akan berubah disesuaikan dengan daya tahan gulma, oleh karena itu perubahan produk tersebut mempengaruhi efektif produk sehingga para petani akan mencari produk yang efektif dan efisien.

\section{Hubungan Keputusan Pembelian Dengan Harapan}

Adapun hubungan antara partisipasi dengan kepercayaan petani dapat dilihat pada Tabel 8.

Tabel 8. Analisis Chi Square Hubungan Antara Partisipasi dengan Kepercayaan Petani di Daerah Penelitian, Tahun 2017

\begin{tabular}{cccccccc}
\hline No & $\begin{array}{c}\text { Tingkat } \\
\text { Partisipasi }\end{array}$ & $\begin{array}{c}\text { Kurang } \\
\text { Setuju }\end{array}$ & Setuju & $\begin{array}{c}\text { Sangat } \\
\text { Setuju }\end{array}$ & Total & $\begin{array}{c}\text { Chi } \\
\text { Squar } \\
\text { e }\end{array}$ & $\begin{array}{c}\text { Asymp } \\
\text {. Sig }\end{array}$ \\
\hline & $\begin{array}{l}139.5-154.5 \\
\mathrm{ml}\end{array}$ & 0 & 3 & 0 & 3 & & \\
\hline 2 & $155-170 \mathrm{ml}$ & 2 & 7 & 0 & 9 & & 0,016 \\
\hline
\end{tabular}




Jurnal IImiah Mahasiswa Pertanian Unsyiah
Volume 2, Nomor 4, November 2017
www.jim.unsyiah.ac.id/JFP

\section{KESIMPULAN DAN SARAN}

\section{Kesimpulan}

Kesimpulan yang dapat diambil dalam penelitian ini adalah berdasarkan hasil analisis diperoleh bahwa keputusan pembelian produk pertanian sangat dipengaruhi oleh persepsi petani yang terdiri dari sikap, motivasi, minat, pengalaman, harapan. Terdapat hubungan antara sikap, motivasi, dan harapan terhadap keputusan pembelian herbisida, sedangkan minat dan pengalaman tidak berhubungan dengan keputusan pembelian.

\section{Saran-Saran}

Agar produk herbisida dapat diterima oleh petani, maka iklan yang ditayangkan disesuaikan dengan kebutuhan petani. Selain itu para petani dalam menggunakan herbisida alangkah baiknya tetap dikonsultasikan dengan para pendamping atau penyuluh dilapangan, dikarenakan tidak semua produk yang diiklankan tersebut efektif terhadap tanaman pada daerah tertentu, hal ini dikarenakan pembuatan produk pertanian tersebut dibuat berdasarkan kondisi alam yang berbeda dengan kondisi alam di daerah penelitian.

\section{DAFTAR PUSTAKA}

Amstrong, Gary \& Philip, Kotler. 2003. Dasar-dasar Pemasaran. Jilid 1, Edisi Kesembilan. Alih Bahasa Alexander Sindoro dan Benyamin Molan. Jakarta: Penerbit Prenhalindo.

Arida, Herdianto, dan Safrid. 2016. Analisis Motivasi Petani Pengrajin Industri Rumah Tangga Gula Aren Di Kecamatan Pining Kabupaten Gayo Lues. JIM Fakultas Pertanian. Vol. 1. No.1 (2016)

Assauri, Sofjan (2007). Manajemen Pemasaran. Penerbit PT Raja Grafindo Persada, Jakarta.

Atsan, T., Isik, H.B., Yavuz, F. dan Yurttas, Z. 2009. Factors Affecting Agricultural Extension Services in Northeast Anatolia Region. African Journal of Agricultural Research 4: 305-310.

Brigade Proteksi Kabupaten Bireuen, Tahun 2014

Dinas Pertanian Kabupaten Bireuen, Tahun 2014. 
Engel, Blackwell, dan Miniard. 1994. Perilaku Konsumen. Jakarta: Binarupa Aksara

Gurel, A. 1998. A Study on the Factors Affecting the Behaviour of Sunflower Producers to Technologic Innovations in Malkara District . Trakya University Tekirdag Faculty of Agriculture. Publication Number: 262. Research Number: 90 . Tekirdag

Jefkins, Frank. 1997. Periklanan. Jakarta : Erlangga

Kotler, Philip dan Amstrong, Garry 2007.Prisip-Prinsip Pemasaran. Jilid I, Edisi ke Delapan, Penerbit Erlangga, Jakarta.

Kotler, Philip. 2011. Manajemen Pemasaran, Edisi Kesebelas, Jilid I, PT Indeks, Jakarta.

Lamb, Hair, McDaniel 2009. Pemasaran. Buku I, Penerbit Salemba Empat, Jakarta.

Machfoedz, Mahmud. 2010. Komunikasi Pemasaran Modern. Yogyakarta : Cakra Ilmu

Mangkunegara, Anwar. Prabu. 2009. Perilaku Konsumen, Edisi Revisi, Cetakan Keempat. Refika, Jakarta.

Mateson, Donald. 2005. Media Discourses: Analyzing Media Texts. New York: Open University Press. 

Jurnal Ilmiah Mahasiswa Pertanian Unsyiah, Vol. 2, No.4, November 2017: 278-287 